\title{
Effect of Ceratonia siliqua Methanolic Extract and 6-hyd roxydopamine on Memory Impairment and Oxidative Stress in Zebrafish (Danio rerio) Model
}

\author{
GABRIELA DUMITRU11, SARA ABIDAR², MOHAMAD NHIRI², LUCIAN HRITCU1, RAZVAN STEFAN BOIANGIU1, ION SANDU3,4, \\ ELENA TODIRASCU-CIORNEA ${ }^{1 *}$ \\ ${ }^{1}$ Alexandru Ioan Cuza University of lasi, Faculty of Biology, Department of Biology, 11 Carol I Blvd., 700506, Iasi, Romania \\ ${ }^{2}$ Laboratory of Biochemistry and Molecular Genetics, Faculty of Science and Technology, Abdelmalek Essaadi University, \\ Tanger, Morocco \\ ${ }^{3}$ Alexandru Ioan Cuza University of Iasi, Faculty of Geography and Geology, 22 Carol I Blvd., 7005056, lasi, Romania \\ ${ }^{4}$ Romanian Inventors Forum, 3 Sf. Petru Movila Str., BI. L11, III/3, 700089, Iasi, Romania
}

The richness in soluble sugars and polyphenols, especially condensed tannins, vitamins, minerals and other phytochemicals, recommends Ceratonia siliqua L. species for use in therapeutic practice, especially in terms of neurotoxicity - a major public health problem. Neurodegenerative disorders arise from various metabolic dysfunctions or from the administration of chemicals such as 6-hydroxydopamine (6-OHDA), a catecholaminergic neurotoxin that induces oxidative stress and, implicitly, cellular apoptosis. The results obtained after the administration of the methanolic extract of carob in Danio rerio highlights a phenomenon of prevention of short-term memory deficits, as well as a significant antioxidant activity.

Keywords: 6-OHDA, carob, Danio rerio, memory, oxidative stress.

Carob is the sweet and edible fruit of a tree of the family Fabaceae (Ceratonia siliqua L.) grown in the Mediterranean region, usually in dry places with poor soil [1], which has the form of a pod with hard walls, dark-brown color with many seeds, having a high food role in the countries of the Mediterranean renowned for edible products of vegetable nature. This species of ecological and economic importance [2] is mainly used for the production of carob gum, widely used in the food industry, both as a thickening agent, and as a stabilizer [3] .

Ceratonia siliqua is characterized by a rich content of soluble sugars and polyphenols, especially condensed tannins, and less proteins and lipids [4], and the flour contains dietary fibers, minerals ( $\mathrm{Fe}, \mathrm{Ca}, \mathrm{Na}, \mathrm{K}, \mathrm{P}$ and $\mathrm{S}$ ), and vitamins among which we can mention vitamins $E, D$, $C, B_{6,}$ folic acid and niacin $[5,6]$. At the same time, the pods carob are used in animal and human food $[7,8]$, and the bark and leaves of this species are used in traditional medicine as anti-inflammatory and anti-ulcer [9], laxative, diuretic, antidiarrhoeal [10], hypoglycemic and in gastroenteritis at infants sugari $[9,11,12]$.

In addition, scientific literature $[13,14]$ reveals the richness in phenolic compounds of $C$. siliqua leaves and pods that have potential anxiolytic and sedative properties [15], antimicrobial and nephroprotective [16, 17], but too antioxidant and antiproliferative activity against human cancers lines (cervical and prostate adenocarcinoma, breast and colon cancer etc.) or against oxidative damage caused by carbon tetrachloride in tissues $[8,18]$.

The present paper summarizes the results on the influence of Ceratonia siliqua methanolic extract (CSME) on antioxidant activity and behavioral manifestations on Danio rerio specimens subjected to 6-hydroxydopamine (6-OHDA) administration.

\section{Experimental part}

\section{Biological material}

It has been worked on Danio rerio raised in guided system, fed with Norvitall (fish flour, cereal flour, yeast, vegetable protein, crustaceans, shrimp, plankton, spirulina, seaweed, lecithin, vegetable oils, aromatic herbs, flatumin, astaxanthin and vitamins $A, D_{3}, E, B_{1}, B_{2}$ and $C$ ). The fish were kept for 10 days to accommodate laboratory conditions, after which they were divided into 5 batches, one control, negative control (treated with 6-OHDA only), and 3 variants with Ceratonia siliqua methanolic extract in concentrations of $0.1 \mathrm{mg} / \mathrm{mL}, 0.3 \mathrm{mg} / \mathrm{mL}$ and $1 \mathrm{mg} / \mathrm{mL}$ water (administered in three consecutive steps, from 3 to 3 days).

At the end of the treatment period, before starting the behavioral tests, both negative control and experimental variants treated with Ceratonia extract were introduced for 60 minutes into an aquarium containing $160 \mu \mathrm{M}$ 6OHDA. After conducting spatial memory test, the fish were used to determine the activity of superoxide-dismutase, catalase and glutathione-peroxidase, respectively the malon-dialdehyde concentration.

\section{Behavioral tasks}

In our studies, zebrafish behaviors were recorded by a Philips Webcam SPC900NC camera and the videos analyzed using ANY-maze ${ }^{\circledR}$ software (Stoelting CO, USA).

\section{Y-maze (spatial memory test)}

The Y-maze task is a specific and sensitive test of spatial recognition memory similar with rodents [19]. Fish were transferred individually in a Y-maze tank with three arms measuring $25 \times 8 \times 15 \mathrm{~cm}$ (length $\times$ width $\times$ height) and filmed for $8 \mathrm{~min}$. The Y-maze center was considered a neutral area, and therefore, it was not counted in the

\footnotetext{
*email:ciornea@uaic.ro
} 
analysis. The percent spontaneous alternation and the locomotor activity (the number of arm entries) was explored.

\section{Assay of oxidative stress parameters}

Biochemical tests consisted in the determination of catalase activity (CAT- by the method based on the spectrophotometric measurement of the resulting chromate acetate by reduction of potassium dichromate by residual hydrogen peroxide after stopping the action of this oxidoreductase), superoxide dismutase (SOD - by the method based on the ability of the enzyme to inhibit the reduction of Nitro-Blue-Tetrazolium by superoxide radicals generated in the reaction medium by photoreduction of riboflavin), glutathione peroxidase (GPX - by spectrophotometric dosing of the compound resulting from the reaction between reduced glutathione excess after reaction with hydrogen peroxide with 5,5-dithiobis-2nitrobenzoic acid at a wavelength of $412 \mathrm{~nm}$ ) and the malon-dialdehyde concentration (MDA - dosed with the 2thiobarbituric acid method) [20 - 23].

\section{Results and discussions}

Neurodegenerative disorders are incurable and madness disorders caused by progressive destruction of neurons resulting in neurological dysfunctions due to nerve cell death causing movement or mental functioning problems such as Parkinson's and Alzheimer's and Huntington's diseases [24].

As shown in figure 1B, 6-OHDA significantly impaired the spatial memory in Y-maze task, as evidenced by significant decrease $(p<0.001)$ of the spontaneous alternation percentage, when compared to control group (fig. 1B). Administration of the CSME, especially at the dose of $1-\mathrm{mg} / \mathrm{mL}$, prevented the effects induced by $6-O H D A$ on memory $(p<0.01)$. The improvement of memory in the CSME groups cannot be attributed to locomotor activity, as evaluated by number of arm entries in the Y-maze test,

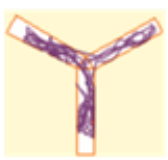

Control

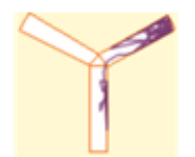

6-OHDA (160uM)

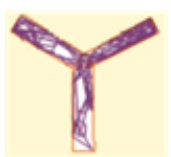

6-OHDA $+\operatorname{CSME}(0.3 \mathrm{mg} / \mathrm{ml})$

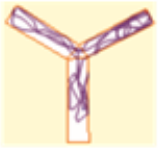

6-OHDA

$+\operatorname{CSME}(0.1 \mathrm{mg} / \mathrm{ml})$

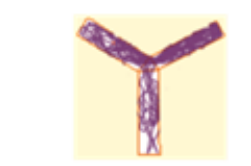

6-OHDA $+\operatorname{CSME}(1 \mathrm{mg} / \mathrm{ml})$
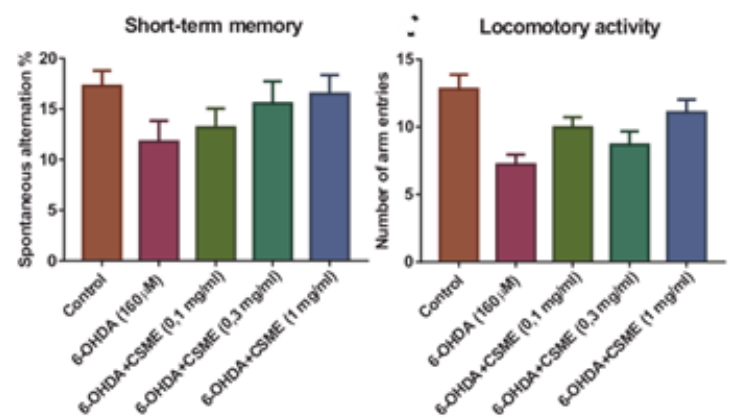

Fig. 1. Effects of Ceratonia siliqua methanolic extract (CSME, $0.1,0.3$ and $1 \mathrm{mg} / \mathrm{mL}$ ) on the spontaneous alternation percentage $(B)$ and number of arm entries (C) in 6-OHDA ( $160 \mu \mathrm{M})$ zebrafish model in the Y-maze test. Data are expressed as mean \pm S.E.M. $(n=10)$. Representative locomotion tracking patterns of all groups (A) because no significant differences between groups were noticed. In the figure $1 A, Y$-maze tracking pattern of the 6 OHDA group showed wrong entries in the Y-maze arms, which were improved following administration of the CSME extract

Our data are in line with previous reports, demonstrated that Ceratonia siliqua methanolic extract prevented shortterm memory deficits [25]. The authors attributed the observed effects to flavonoids and polyphenolic compounds via their antioxidative activity in protected against neurodegeneration.

In vitro various studies have shown that the extracts of Ceratonia siliqua have a strong antioxidant effect $[26,27]$, the antioxidant capacity of this species due to its strong cleaning and removal effect of reactive oxygen and free radicals, as well as inhibition of myeloperoxidase activity in a manner dependent of concentration $[28,29]$.

Therefore, another objective of our study was to determine the activity of oxidative stress enzymes by first evaluating SOD - the enzyme involved in the fight against reactive oxygen species by converting the superoxide radicals into hydrogen peroxide and oxygen [30]. The analysis of experimental results in Danio rerio highlights the existence of significant differences between the reference group, the negative control and the three experimental variants.

Thus (fig. 2), if in the case of the sample treated with 6OHDA only, the SOD activity showed average values of $0.109 \pm 0.009 \mathrm{USOD} / \mathrm{mg}$ protein, at the reference group the enzyme showed an average activity of almost twice as high $(0.198 \pm 0.023 \mathrm{USOD} / \mathrm{mg}$ protein), while in the variants treated with Ceratonia siliqua methanolic extract, the enzymatic activity recorded increasing values from the lowest to the highest concentration of extract used, in the group treated with $0.1 \mathrm{mg}$ of extract $/ \mathrm{mL}$ of water the mean value being of $0.271 \pm 0.024 \mathrm{USOD} / \mathrm{mg}$ protein, and those containing $0.3 \mathrm{mg}$ of extract $/ \mathrm{mL}$ of water, respectively 1 $\mathrm{mg}$ of extract $/ \mathrm{mL}$ of water, the activity ascends to levels of $0.333 \pm 0.013 \mathrm{USOD} / \mathrm{mg}$ protein and $0.363 \pm 0.014$ USOD/ mg protein.

In addition, the literature highlights the fact that Ceratonia siliqua has important pharmacodynamic properties due to the high antioxidant capacity, the latter being due to the ability to remove radicals and inhibit lipid peroxidation [31].

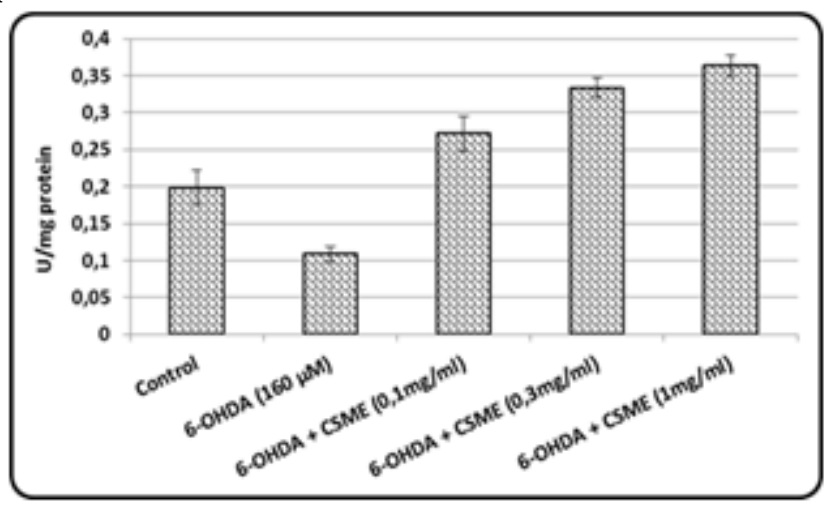

Fig.2. SOD activity in Danio rerio under the influence of methanolic extract of Ceratonia siliqua

Concerning CAT activity, oxidoreductase involved in cell detoxification processes by converting hydrogen peroxide into water and oxygen [32,33], an average activity of $14.697 \pm 0.948 \mathrm{UCAT} / \mathrm{mg}$ protein in the control group was observed (fig. 3), so that in the variant treated with 6-OHDA it decreased to $9.463 \pm 0.383$ UCAT/mg protein, while in the samples treated with $0.1 \mathrm{mg}$ of carob extract $/ \mathrm{mL}$, respectively $1 \mathrm{mg}$ of carob extract $/ \mathrm{mL}$ of water, the 
thresholds of activity are of $15.34 \pm 0.678 \mathrm{UCAT} / \mathrm{mg}$ protein, respectively $15.11 \pm 1.062 \mathrm{UCAT} / \mathrm{mg}$ protein, the highest mean being observed in the treated group with $0.3 \mathrm{mg}$ of carob extract $/ \mathrm{mL}$ of water $(17.533 \pm 0.678 \mathrm{UCAT} / \mathrm{mg}$ protein).

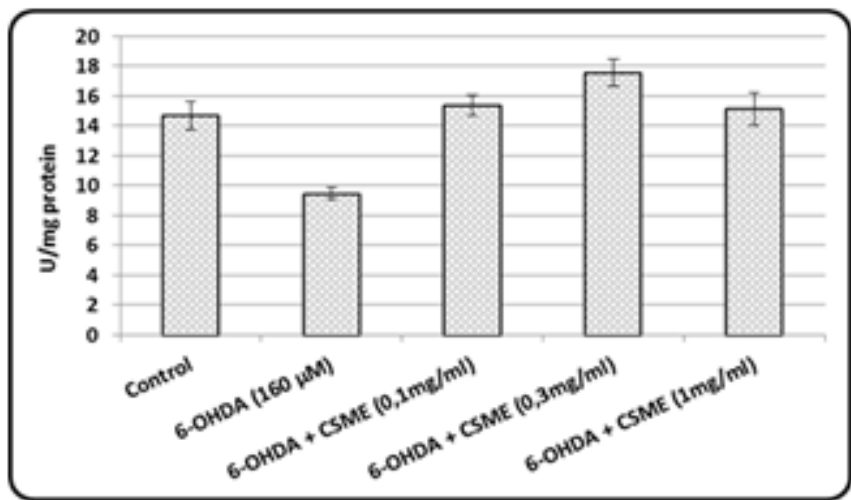

Fig.3. CAT activity in Danio rerio under the influence of methanolic extract of Ceratonia siliqua

Another component of the antioxidant system is GPX, an enzyme with primary role in maintaining cellular homeostasis, being in the same time one of the most useful biomarkers of oxidative stress for a wide variety of aquatic organisms from polluted environments $[23,34,35]$.

From figure 4 it is observed that in lot 2 (treated with 6OHDA only) GPX recorded the lowest value threshold $(0.0159 \pm 0.002 \mathrm{UGPX} / \mathrm{mg}$ protein), while in the reference and treated groups with $0.1 \mathrm{mg}$ of carob extract $/ \mathrm{mL}$ of water enzyme exhibits mean values of $0.043 \pm 0.002$ UGPX/mg protein, respectively $0.049 \pm 0.003 \mathrm{UGPX} / \mathrm{mg}$ protein. Also, with increasing the concentration of Ceratonia siliqua methanolic extract, is observed an increase in the mean values of the activity of this oxidoreductase in the groups treated with $0.3 \mathrm{mg}$ of carob extract $/ \mathrm{mL}$ of water and $1 \mathrm{mg}$ of carob extract $/ \mathrm{mL}$ of water, respectively $(0.056 \pm 0.003 \mathrm{UGPX} / \mathrm{mg}$ protein, respectively $0.073 \pm 0.003$ UGPX/mg protein).

Literature field $[36,37]$ mentions that when fish are exposed to oxidative stress conditions, peroxidation of polyunsaturated fatty acids can occur, a product of oxidation of these acids which indicates the level of peroxidation the lipid being MDA, an indicator that influences the integrity of cell membranes.

In the control group, MDA recorded the lowest value of $0.043 \pm 0.001 \mathrm{nmol} / \mathrm{mg}$ protein, while the highest threshold was highlighted in the variant treated with 6-OHDA only $(0.736 \pm 0.054 \mathrm{nmol} / \mathrm{mg}$ protein). Applying the treatment with methanolic extract of carob resulted in the decrease of the MDA concentration, as compared to the values recorded in the negative control, regardless of the amount

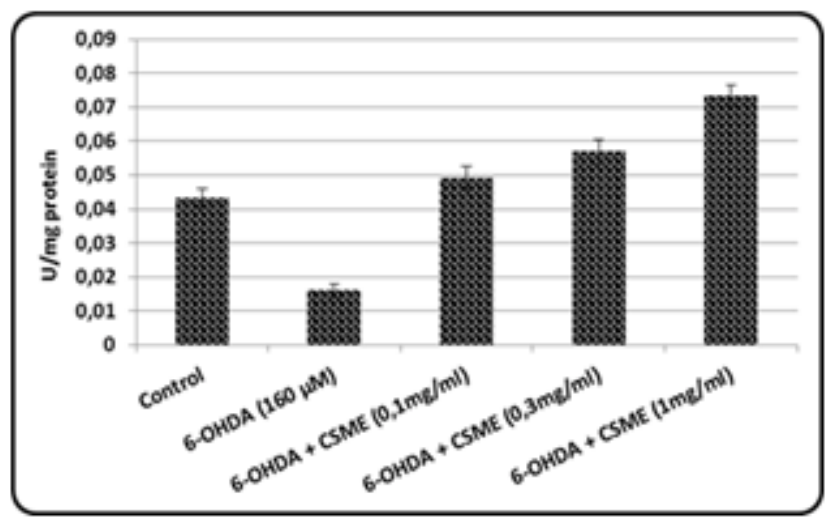

Fig.4. GPX activity in Danio rerio under the influence of methanolic extract of Ceratonia siliqua of administered extract (fig. 5). Thus, if on the sample treated with $0.1 \mathrm{mg}$ of carob extract $/ \mathrm{mL}$ water MDA recorded an average concentration of $0.679 \pm 0.032 \mathrm{nmol} /$ $\mathrm{mg}$ of protein, in the group treated with $0.3 \mathrm{mg}$ of carobextract $/ \mathrm{mL}$ water the values decreased to $0.57 \pm 0.029 \mathrm{nmol} / \mathrm{mg}$ protein, so in the case of the last experimental variant (treated with $1 \mathrm{mg}$ of carob extract/ $\mathrm{mL}$ of water) to reach the lowest level $(0.482 \pm 0.034 \mathrm{nmol} /$ mg protein).

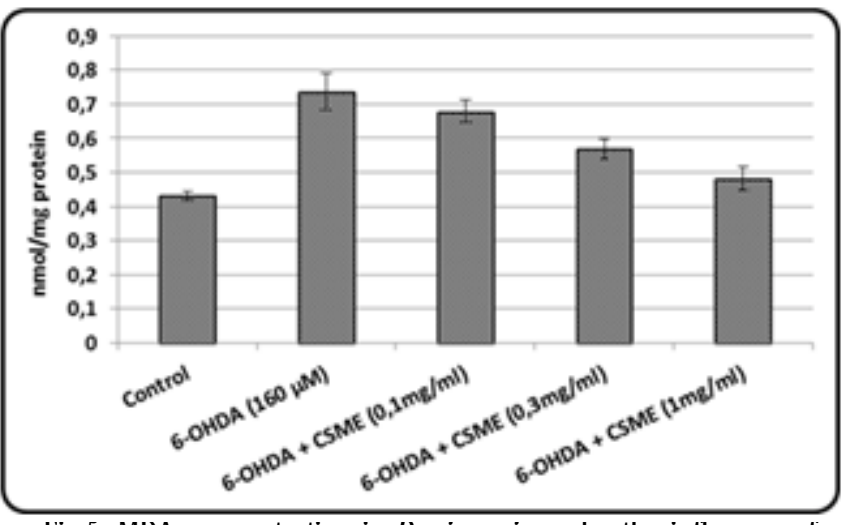

rıg.b. IMUA concentratıon in Vanıo rerıo under the intluence of methanolic extract of Ceratonia siliqua

\section{Conclusions}

The experimental results on the effects of CSME and 6 OHDA on Danio rerio allowed us to formulate the following general conclusions:

- the carob extract has prevented short-term memory damage, in close correlation, probably, as other speciality studies suggest, with the richness of this species in phytochemical compounds with high pharmacodynamic and therapeutic action;

- Ceratonia siliqua species has an appreciable antioxidant capacity, due to the ability to remove radicals and inhibit lipid peroxidation, the activity of oxidative stress enzymes being clearly superior to the reference lot, closely related to the concentration of the methanolic extract used.

\section{References}

1.VON HASELBERG, C., Vegetative growth and flower and fruit development in carob trees (Ceratonia siliqua L.) with special emphasis on environmental conditions at marginal production sites in South Portugal. PhD. Thesis, Humboldt-Universitat zu Berlin Landwirtschaftlich-Gärtnerische Fakultat Institut fur Gartenbauwissenschaften Fachgebiet Obstbau, 2000, DOI: 10.13140/ 2.1.3414.3048

2. BATLLE, I., TOUS, J., Carob tree. Ceratonia siliqua L. Promoting the Conservation and Use of Underutilized and Neglected Crops. vol. 17. Institute of Plant Genetics and Crop Plant Research, Gatersleben/ International Plant Genetic Resources Institute, Rome, Italy, 1997. 3.SASSI, A., BOUHLEL, I., MUSTAPHA, N., MOKDAD-BZEOUICH, I., CHAABANE, F., GHEDIRA, K., CHEKIR-GHEDIRA, L., Regulatory Toxicology and Pharmacology, 77, 2016, p. 117.

4. SECZYK, L., SWIECA, M., GAW LIK-DZIKI, U., Food Chemistry, 194, 2016, p. 637.

5. ORTEGA, N., MACIA, A., ROMERO, M.-P., REGUANT, J., MOTILVA, M.-J., Food Chemistry, 124, no. 1, 2011, p. 65.

6. YOUSSEF, M.K.E., EL-MANFALOTY, M.M., ALI, H.M., Food Chemistry, 3, no. 6, 2013, p. 304.

7.BINER, B., GUBBUK, H., KARHAN, M., AKSU, M., PEKMEZCI, M., Food Chemistry, 100, no. 4, 2007, p. 1453.

8. HSOUNA, A.B., SAOUDI, M., TRIGUI, M., J AMOUSSI, K., BOUDAWARA, T., JAOUA, S., EL FEKI, A., Food and Chemical Toxicology, 49, 2011, p. 3183. 
9.RTIBI, K., SELMI, S., GRAMI, D., AMRI, M., ETO, B., EL-BENNA, J., SEBAI, H., MARZOUKI, L., Biomedicine and Pharmacotherapy, 93, 2017, p. 522.

10. GULAY, M.S., YILDIZ-GULAY, O., ATA, A., BALIC, A., DEMIRTAS, A., J. Animal Vetern. Adv., 11, 2012, p. 1853.

11. MOKHTARI, M., SHARIFI, S., SHAHAMIR M.T. International Conference on Life Science and Technology, 3, 2011, p. 82.

12. RTIBI, K., SELMI, S., GRAMI, D., SAIDANI, K., SEBAI, H., AMRI, M., ETO, M., MARZOUKI, L., J ournal of the Science of Food and Agriculture, 97, no. 8, 2017, p. 2664.

13. CUSTÓDIO, L., ESCAPA, A.L., FERNANDES, E., FAJARDO, A., ALIGUÉ, R., ALBERÍCIO, F., NENG, N., NOGUEIRA, H.M.F., ROMANO, A., J. Med. Plants. Res., 5, no.10, 2011, p. 987.

14. GHANEMI, F.Z., BELARBI, M., FLUCKIGER, A., NANI, A., DUMONT, A., DE ROSNY, C., ABOURA, I., SAYED KHAN, A., MURTAZA, B., BENAMMAR, C., FARID LAHFA, B., PATOLI, D., DELMAS, D., RÉBÉ, C., APETOH, L., AKHTAR KHAN, N., GHRINGHELLI, F., RIALLAND, M., HICHAMI, A., Journal of Functional Foods, 33, 2017, p. 112.

15. AVALLONE, R., COSENZA, F., FARINA, F., BARALDI, C., BARALDI, M., Fitoterapia, 73, no. 5, 2002, p. 390.

16. AISSANI, N., CORONEO, V., FATTOUCH, S., CABONI, P., J ournal of Agricultural and Food Chemistry, 60, no. 40, 2012, p. 9954.

17. AHMED, M., Nature and Science, 8, 2010, p. 41.

18. AMESSIS-OUCHEMOUKHA, N., OUCHEMOUKH, S., MEZIANT, N., IDIRI, Y., HERNANZ, D., STINCO, C.M., RODRÍGUEZ-PULIDO, F.J., HEREDIA, F.J., MADANI, K., LUIS, J., Industrial Crops and Products, 95, 2017, p. 6.

19. IONITA, R., POSTU, P.A., MIHASAN, M., GORGAN, D.L., HANCIANU, M., CIOANCA, O., HRITCU, L., Phytomedicine, 47, 2018, p. 113.

20. DOBRIAN, A.D., DAVIES M.J., SCHRIVER S.D., LAUTERIO T.J ., PREWITT R.L., Hypertension, 37, 2001, p. 554.

21. COJOCARU, D.C., Enzimologie practicã. Ed. Tehnopress, Iasi, 2005.

22. PINTILIE, O., ION, L., SURLEVA, A., ZAHARIA, M., TODIRASCU CIORNEA, E., CIUBOTARIU, E., BALAN, A., DROCHIOIU, G., SANDU, I., Rev. Chim. (Bucharest), 67, no. 4, 2016, p. 687.
23. DUMITRU, G., TODIRASCU CIORNEA, E., HRITCU, L., SANDU, I.G., Rev. Chim. (Bucharest), 69, no. 5, 2018, p. 1194.

24. IH EL-SAYYAD, H., ELKHOLY, W.M.E., HAMED, W.A.E., Glob. J. Zool., 2, no. 1, 2017, p. 24.

25. ALZOUBI, K.H., ALIBBINI, S., KHABOUR, O.F., EL-ELIMAT, T., ALZUBI, M., ALALI, F.Q., J. Mol. Neurosci., 66, no. 3, 2018, p.314.

26. EL HAJAJI, H., LACHKAR, N., ALAOUI, K., CHERRAH, Y., FARAH, A. ENNABILI, A., EL BALI, B., LACHKAR, M., Arab. J. Chem., 4, 2011, p. 321.

27. SEBAI, H., SOULI, A., CHEHIMI, L., RTIBI, K., AMRI, M., EL-BENNA, J., SAKLY, M., J. Med. Plant Res., 7, 2013, p. 85.

28. RTIBI, K., JABRI, M.A., SELMI, S., SOULI, A., SEBAI, H., EL-BENNA, J., AMRI, M., MARZOUKI, L., RSC Adv., 5, 2015, p. 84207.

29. RTIBI, K., JABRI, M.A., SELMI, H., SEBAI, S., AMRI, M., EL-BENNA, J., MARZOUKI, L., RSC Adv., 6, 2016, p. 65483.

30. BORKOVIC, S.S., SAPONJIC, J.S., PAVLOVIC, S.Z., BLAGOJEVIC, D.P., MILOSEVIC, S.M., KOVACEVIC, T.B., RADOJICIC, R.M., SPASIC, M.B., ZIKIC, R.V., SAICIC, Z.S., Comp. Bioch. Physiol., 141C, 2005, p. 366.

31. KUMAZAWA, S., TANIGUCHI, M., SUZUKI, Y., SHIMURA, M., KWON, M., NAKAYAMA, T., J. Agric. Food Chem., 50, 2002, p. 373.

32. GOYAL, M.M., BASA, K.A., Protein Cell, 1, no. 10, 2010, p. 888.

33. DUMITRU, G., DIRVARIU, L., BARBACARIU, C.A., MIRON, I., SANDU, I., TODIRASCU CIORNEA, E., Rev. Chim. (Bucharest), 69, no. 11, 2018, p. 3146.

34. COSSU, C., DOYOTTE, A., JACQUIN, M.C., BABUT, M., EXINGER, A., VASSEUR, P., Ecotoxicol. Environ. Saf., 38, 1997, p. 122.

35. NONGMAITHEM, R., LODHI, M.S., SAMAL, P.K., DHYANI, P.P., SHARMA, S., International J ournal of Conservation Science, 7, no. 2, 2016, p. 523.

36. ERCAL, N., GURER-ORHAN, H., AYKIN-BURNS, N., Current Topics in Medicinal Chemistry, 1, 2001, p. 529.

37. ALMROTH, B.C., STURVE, J., BERGLUND, A., FORLIN, L., Aquat. Toxicol., 73, 2005, p. 171.

$\overline{\text { Manuscript received:23.08.2018 }}$ 